\title{
First record of Mansoa minensis M.M.Silva-Castro (Bignoniaceae, Bignonieae) in Espírito Santo, Brazil
}

\author{
Renata Giassi Udulutsch ${ }^{1}$, Geovane Souza Siqueira ${ }^{2}$, Pedro Dias ${ }^{3}$
}

1 Universidade Estadual Paulista Júlio de Mesquita Filho (UNESP), Faculdade de Ciências e Letras de Assis, 19806-900, Assis, SP, Brazil. 2 Herbário, Reserva Natural Vale, 29927-000, Caixa Postal 91, Sooretama, ES, Brazil. 3 Escola de Artes, Ciências e Humanidades, Universidade de São Paulo (USP), 03828-000, São Paulo, SP, Brazil.

Corresponding author: Renata Giassi Udulutsch, udulutsch@gmail.com

\begin{abstract}
Mansoa minensis M.M.Silva-Castro is reported for the first time for the state of Espírito Santo, Brazil. We provide an updated description, comparisons with closely related species, and suggest a revised conservation status for this species. We also present an identification key for all species of Mansoa that occur in Espírito Santo.
\end{abstract}

Key words

Atlantic Forest; endemism; IUCN categories.

\section{Introduction}

The family Bignoniaceae comprises about 840 species (Olmstead et al. 2009). Although the family has a pantropical distribution, most of its species diversity is concentrated in the Neotropics (ca. 78\% of the species, Gentry 1980). In this family, Bignonieae is the largest tribe with 21 genera and 393 species (Lohmann and Taylor 2014). From a phylogenetic point of view, the tribe Bignonieae and several of its genera seem to be monophyletic (Lohmann 2006).

Mansoa is a Neotropical genus comprising 16 species and occurs from Mexico to Argentina (Silva-Castro and Queiroz 2016). Morphologically, Mansoa is characterized by the lianescent habit, garlic or onion odor, leaflets with venation acrodromous imperfect, (supra) basal, trifid tendrils, and corolla usually pink to purple. The genus is widely distributed in Brazil in all vegetation types including rainforests, seasonal semideciduous forests, and savanna formations (Silva-Castro and Queiroz 2016), and all species occur in Brazil but M. gentryi M.M. Silva, which is endemic to Peru. As already stated by several authors (e.g., Gentry 1991, Udulutsch et al. 2010), the lianescent life form is usually neglected in most botanical surveys, which leads to the lack of herbarium collections and basic information about the ecology and geographical distribution of the species is uncertain.

During a floristic survey in the main forest fragments near to CVRD Reserve (Linhares, ES, Brazil), we found a new record of Mansoa from Espírito Santo state: $M$. minensis M.M.Silva-Castro, which was known only from Minas Gerais state.

\section{Methods}

The species was identified by consulting the protologue and specific literature on the genus (Silva-Castro 2010, Silva-Castro and Queiroz 2016), morphological analy- 


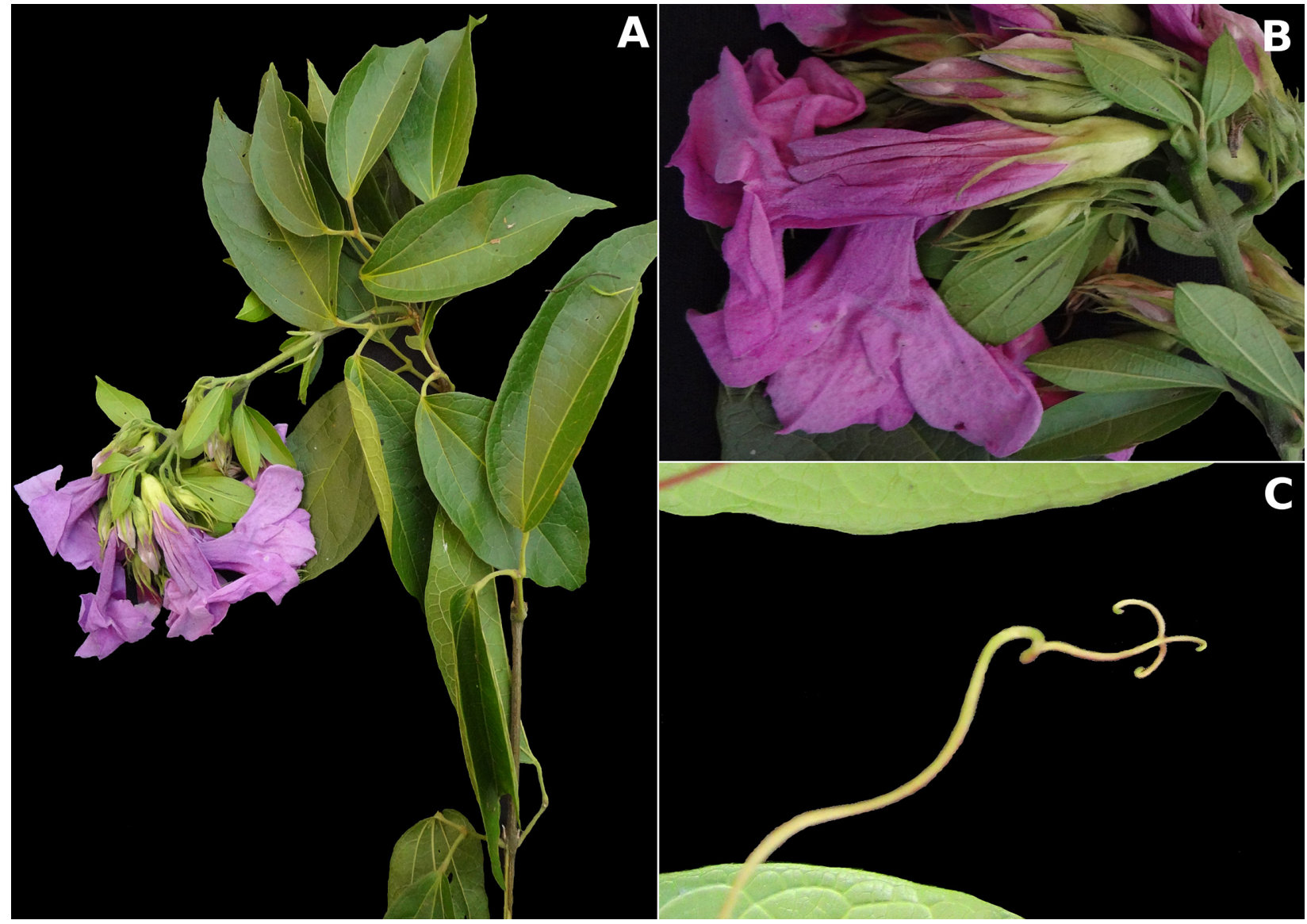

Figure 1. Mansoa minensis M.M.Silva-Castro. A. Fertile branch. B. Detail of the inflorescence and calyx. C. Trifid tendril.

ses of herbarium specimens, and comparison to type specimen images as well. The collected and examined specimens were deposited at CVRD and HASSI herbaria. Only fully developed structures were used for the morphological description. Terms used to describe twodimensional shapes follow Hickey (1973), those used to describe indumentum are according to Payne (1978). Inflorescence type is according to Weberling (1989).

\section{Results}

New record. Brazil. Espírito Santo, Rio Bananal, road from Rio Bananal to São Jorge $\left(19^{\circ} 12^{\prime} 51.5^{\prime \prime} \mathrm{S}\right.$, 040²1'24.6" W), 5 Sept. 2012, fl., D.A. Folli 6907 (CVRD 13876, HASSI 1172).

Additional specimens examined. Brazil. Minas Gerais: Padre Paraíso, Rodovia BR 116, km 192-193, 15 July 1988, fl., G. Hatschcbach \& G. Hatschcbach 52176 (BHCB).

\section{Mansoa minensis M.M.Silva-Castro.}

\section{Figure 1}

Type: Brazil. Minas Gerais: Marliéria, Rio Doce State Park, road to the restaurant, $19^{\circ} 46^{\prime} 34.5^{\prime}$ 'S $42^{\circ} 36^{\prime} 8.5^{\prime \prime} \mathrm{W}$, 2 Sept. 2008, M.M. Silva-Castro, R.P. Oliveira, J.G. Carvalho-Sobrinho \& F.M. Ferreira 1475 (Holotype HUEFS 140999!, Silva-Castro and Queiroz 2016).

Liana with garlic odor; branchlets brown when dried, without lenticels, striated, puberulous, trichomes simple and white to grayish; interpetiolar area without nectaries; axillary shoot with persistent prophylls; prophylls $4.0-8.0 \times 1.0-1.5 \mathrm{~mm}$, lanceolate, falcate, apex acuminate, puberulous, tricomas tectores simples, venation inconspicuous. Leaves petiolate; petiole 1.4-2.2 cm long, semiterete, puberulous; lateral petiolules $0.9-1.3 \mathrm{~cm}$ long; terminal petiolule $2.6 \mathrm{~cm}$, semiterete, puberulous; shorter leaves at the base of inflorescences, petiole $0.5-0.6 \mathrm{~cm}$, lateral petiolules $0.2-0.4 \mathrm{~cm}$, terminal petiolule caducous. Tendrils trifid. Leaflet blades concolor when dry, opaque, chartaceous, margin flat, with prominent venation on both sides, venation acrodroumous imperfect basal, adaxial side with sparse trichomes and abaxial side puberulous when young, trichomes concentrated on the veins on both sides, nectaries pateliform, concentrated between primary and secondary veins; lateral leaflets $6.1-10.2 \times 2.6-4.5$ $\mathrm{cm}$, lanceolate to elliptic, apex acuminate and mucronulate, base slightly asymmetric, acute to rounded; terminal leaflet $5.5 \times 1.4 \mathrm{~cm}$, elliptic, apex acuminate and mucronulate, base asymmetric, acute. Inflorescences thyrsoid, axillary or terminal, lax, brown when dry; peduncule 1.0-1.2 cm long, rachis 4.5-7.0 cm, puberulous, tector trichomes simple and white to grayish, scales lustrous, orangish yellow when dried; bracts persistent, 4.0-6.1 mm long, linear, filiform, with inconspicuous venation, puberulous. Flowers pedicellate; pedicel 1.5-3.0 $\mathrm{mm}$, puberulous. Calyx green, campanulate, $1.4-2.2 \times 0.5-0.9 \mathrm{~cm}$, nectar glands lacking; lobes $1.1-1.4 \times 0.2-0.5 \mathrm{~cm}$, triangular, 


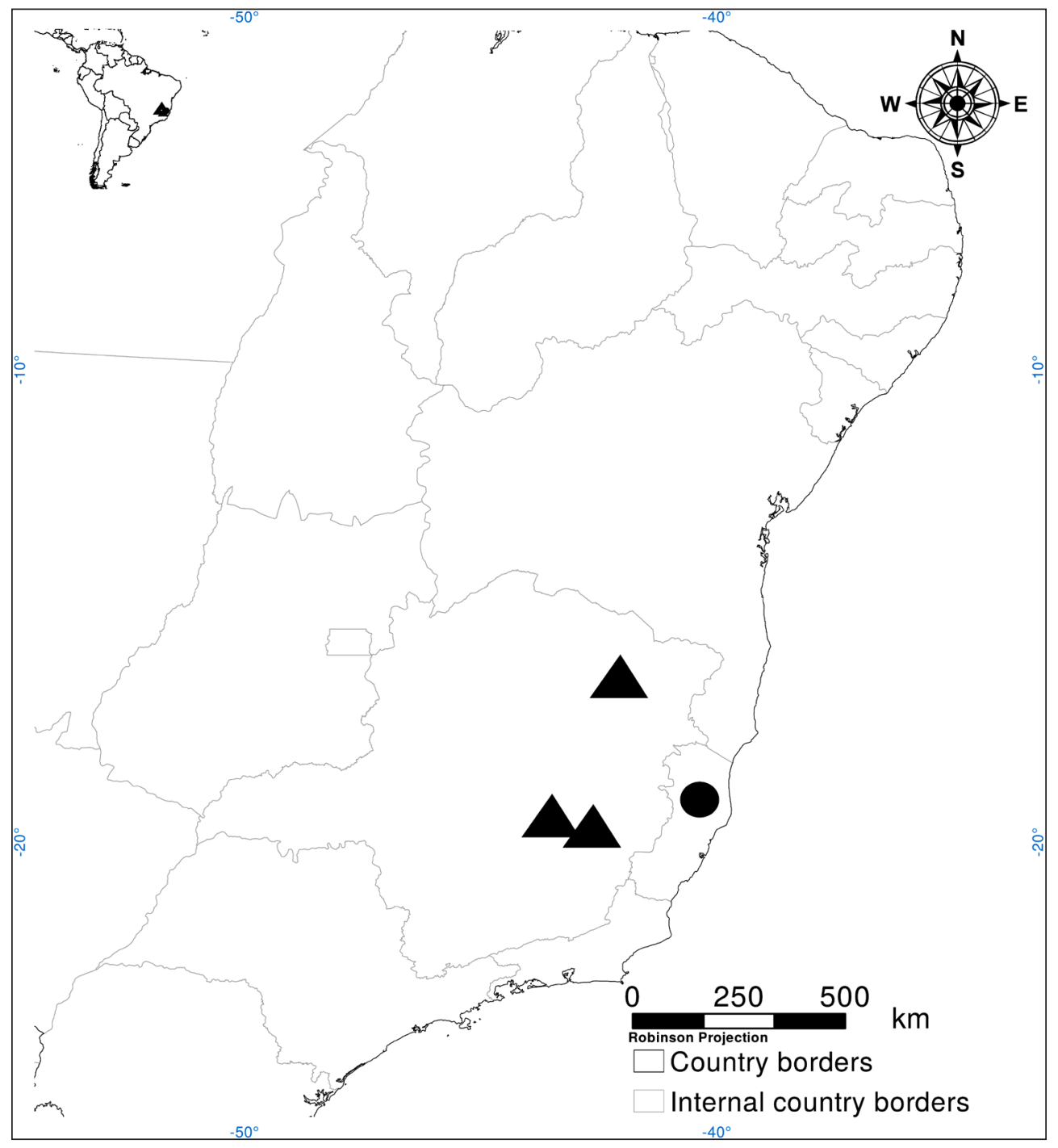

Figure 2. Map showing the current distribution of Mansoa minensis in the states of Minas Gerais (triangles) and Espírito Santo (circle), Brazil.

apex acuminate, pilose outside, papillose inside. Corolla purple, with basal portion of the tube whitish, tubularcampanulate; tube $3.0-3.6 \mathrm{~cm}$ long, $1.5-2.2 \mathrm{~cm}$ wide at the mouth, the cylindric base of the tube $0.9-1.1 \times 0.3-0.5$ $\mathrm{cm}, 1 / 3$ superior puberulous outside, glabrous inside but glandular-tomentose at the level of stamen insertion; lobes $1.2-1.7 \times 1.0-1.4 \mathrm{~cm}$, obovate to rounded, obtuse at apex, puberulous on both sides. Stamens 4 , included, longer filaments $2.1-2.3 \mathrm{~cm}$ long, shorter filaments $1.4-1.6 \mathrm{~cm}$ long, glabrous; anthers 3.0-4.0 mm long, connective apiculate, $1.2 \mathrm{~mm}$ long., glabrous; staminode 5.0-6.0 mm long, with lanceolate apex, membranaceous, glabrous. Disc annular 1.0-1.2 ×2.8 mm. Ovary $3.5 \times 1.8 \mathrm{~mm}$, subcylindric, pubescent; ovules 4-seriate, 18-20 per series; style 2.9-3.1 $\mathrm{cm}$ long, glabrous, stigma $4.0 \times 1.5 \mathrm{~mm}$, ovate. Fruit not seen, description based in Silva-Castro and Queiroz (2016): capsule smooth, 20.5-22 $\times 1-3 \mathrm{~cm}$, apex acuminate, with irregular margin re-entrances, base acuminate; pubescent valves, peltate glandular trichomes, irregularly prominent midrib, calyx persistent. Seeds not seen.

In several herbaria, this species is often identified as Mansoa hirsuta DC. due to the strong garlic smell. However, M. hirsuta has calyx with 2-3 lobes and ovary with
2 series of ovules per locule (versus calyx with 5 lobes and ovary with 4 series of ovules per locule in M. minensis). Morphologically, M. minensis is similar to M. ivanii M.M. Silva, as both species have calyx with 5 lobes. However, M. minensis has corolla with lobes acuminate at the apex, included stamens and garlic smell (versus corolla with lobes slightly emarginate and mucronate at the apex, subexserted stamens, and onion smell, SilvaCastro and Queiroz 2016).

\section{Key to species of Mansoa reported from Espírito Santo}

1a Interpetiolar glands present M. hymenaea

1b Interpetiolar glands absent 2

2a Calyx with nectar glands 3

2b Calyx lacking nectar glands 4

3a Calyx minutely 5-toothed M. difficilis

3b Calyx 2- to 3-lobed M. glaziovii

4a Plants without garlic odor; corolla cream, with a yellow tube M. lanceolata

4b Plants with garlic odor; corolla purple 
5a Calyx truncated to minutely 5-toothed; capsule verrucosus M. onohualcoides

5b Calyx 5-lobed; capsule smooth M. minensis

Distribution. Brazil: Minas Gerais (Caratinga, Dionísio, Marliéria and Padre Paraíso; Silva-Castro and Queiroz 2016); Espírito Santo (Rio Bananal) (Figure 2).

\section{Discussion}

Mansoa minensis was previously known from a few areas of semideciduous seasonal forest in Minas Gerais (Silva-Castro and Queiroz 2016) and is now known from Espírito Santo (Fig. 2). We found this species with flowers in September.

In the protologue, $M$. minensis is ranked as Least Concern, because this species was known to occur within a conservation unit. Although the discovery of M. minensis in Espírito Santo meaningfully extends the eastern range of this species by ca $200 \mathrm{~km}$, this species is believed to be rare and restricted, as it is known from only a few herbarium collections.

The population of $M$. minensis was reported in 5 severely fragmented localities, with EOO (extent of occurrence) estimated as $500 \mathrm{~km}^{2}$ and AOO (area of occupancy) estimated as $20 \mathrm{~km}^{2}$. Anthropic activities can endanger this population, especially outside the conservation units, where livestock and agriculture are expanding. Therefore, following IUCN criteria (IUCN 2012, 2014), M. minensis should be considered as Endangered (B2a, B2b).

\section{Acknowledgements}

We are deeply indebted to Drs Miriam Kaehler and Marcelo Trovó for providing invaluable suggestions. We also thank the Department of Biological Sciences (Universidade Estadual Paulista "Júlio De Mesquita Filho", Faculdade de Ciências e Letras de Assis,) and the Vale Natural Reserve for providing the necessary support for our survey.

\section{Authors' Contributions}

RGU identified the species, GSS collected samples, and RGU, GSS and PD wrote the manuscript.

\section{References}

Gentry AH (1980) Bignoniaceae. Part I (Crescentiae and Tourrettieae). Flora Neotropica 25: 1-130.

Gentry AH (1991) The distribution and evolution of climbing plants. In: Putz FE, Mooney HA (Eds) The Biology of Vines. Cambridge University Press, Cambridge, 3-49.

Hickey LJ (1973) Classification of the architecture of dicotyledonous leaves. American Journal of Botany 60: 17-33.

IUCN (2012) IUCN Red List Categories and Criteria: version 3.1. Second edition. IUCN, Gland, Switzerland and Cambridge, 32 pp. https://portals.iucn.org/library/efiles/documents/RL-2001-0012nd.pdf. Accessed on: 2017-12-10.

IUCN (2014) Guidelines for Using the IUCN Red List Categories and Criteria, Version 13. Prepared by the Standards and Petitions Subcommittee in March 2017. http://cmsdocs.s3.amazonaws.com/ RedListGuidelines.pdf. Accessed on: 2018-03-06.

Lohmann LG (2006) Untangling the phylogeny of Neotropical lianas (Bignonieae, Bignoniaceae).American Journal of Botany 93 (2): 304-318. https://doi.org/10.3732/ajb.93.2.304

Lohmann LG, Taylor CM (2014) A new generic classification of tribe Bignonieae (Bignoniaceae). Annals of the Missouri Botanical Garden 99 (3): 348-489. https://doi.org/10.3417/2003187

Olmstead RG, Zjhra ML, Lohmann LG, Grose SO, Eckert AJ (2009) A molecular phylogeny and classification of Bignoniaceae. American Journal of Botany 96 (9): 1731-1743. https://doi.org/10.3732/ ajb.0900004

Payne WW (1978) A glossary of plant hair terminology. Brittonia 30 (2): 239-255. https://doi.org/10.2307/2806659

Silva-Castro MM (2010) Estudos taxonômicos, filogenéticos e biossistemáticos em Mansoa DC. (Bignonieae, Bignoniaceae). PhD thesis, Universidade Estadual de Feira de Santana, Feira de SantanaBrasil, 293 pp.

Silva-Castro MM, Queiroz LP (2016) Five new species of Mansoa DC. (Bignoniaceae) from South America. Phytotaxa 258 (1): 49-62. https://doi.org/10.11646/phytotaxa.258.1.3

Udulutsch RG, Souza VC, Rodrigues RR, Dias P (2010) Composição florística e chaves de identificação para as lianas da Estação Ecológica dos Caetetus, estado de São Paulo, Brasil. Rodriguésia 61 (4): 715-730.

Weberling F (1989) Morphology of Flowers and Inflorescences. Cambridge University Press., Cambridge, 405 pp. 